\title{
The northern corridor - economic communication solution in the Częstochowa infrastructure
}

\author{
Katarzyna Regulska ${ }^{1}$
}

\begin{abstract}
:
Northern corridor - economic communication solution in the Częstochowa infrastructure The article presents realized and planned road investments influencing the economic transport solutions of the Częstochowa city. An assessment of the impact of the road investment, so-called The Northern Corridor, for communication economics including the implementation of the intended communication effect was made. Other realized and planned communication investments for the Częstochowa city were also indicated. The summary points to the desirability of improving the economy of the vehicular traffic of the Częstochowa city, which will also have a significant impact on the development of the city.
\end{abstract}

\section{KEYWORDS}

road infrastructure; highways; expressways; national roads; Częstochowa road network

\section{Introduction}

In Poland, thanks to the European Funds allocated to road construction, viaducts, city ring roads, collision-free expressways and motorways are being built. As a member of the European Union, Poland is obliged to implement the infrastructure of the trans-European road network TEN-T. The assumption is that the core network will be created by 2030 , and the comprehensive network by 2050. The route of both these networks in Poland was established by the Regulation of the European Parliament and of the Council (EU) No. 1315/2013 of December 11, 2013 [1]. Appropriate funds and programs are created in order to implement the intended undertakings. The goal is to create a coherent trans-European transport network. An efficiently functioning transport system within the EU is to contribute to the improvement of the operation of the single internal market, stimulate the economic growth of the region, and increase the competitiveness of individual Member States and the entire EU on a global scale.

As part of the fund: European Regional Development Fund, in the program: Regional Operational Program of the Śląskie Voivodeship (Infrastructure and Environment), action was taken to modernize and expand key elements of the road network. In the field of transport, a project entitled "Construction of the Northern Corridor in Częstochowa" [2]. The City of Częstochowa was the beneficiary. The construction of this facility, apart from its national importance, has a significant impact on the economic solution of the urban transport road network.

\section{Infrastructure and economic conditions}

Częstochowa, as a city with poviat rights, is an important administrative, economic, educational and cultural center in the Silesian Voivodeship. As such, it participates in the creation of the core transport network, starting from the construction of local streets, through district and national roads (DK1), to the construction of the A1 motorway with the Częstochowa bypass [3].

1 Czestochowa University of Technology, Faculty of Civil Engineering, ul. Akademicka 3, 42-218 Częstochowa, e-mail: katarzyna.regulska@pcz.pl, orcid id: 0000-0002-7966-7048 
The city participates in the economic development of Poland, including creating the so-called economic zones. In order to attract investors to these zones, the city invested in the proper preparation of the zones, including road networks. Companies based in such zones employ thousands of people. In addition to the inhabitants of Częstochowa, workers also include inhabitants of nearby villages and towns. One of the very important activities is to create the possibility of fast, efficient and economic transport both within the city and with cooperating centers in Silesia and throughout Poland $[4,5]$. With the completion of the motorway ring road construction, the city authorities are counting on more entrepreneurs investing in economic zones and beyond. Apart from the construction of the aforementioned bypass, this goal is to be served by the expansion and improvement of transport within the city.

\section{Planned and implemented road investments}

Częstochowa takes part in many competitions for investment projects selected for co-financing from EU funds. Many construction plans have already been approved and accepted for implementation. As part of the competition entitled "Increasing the transport accessibility of urban centers located in the TEN-T road network and relieving cities from excessive road traffic" the city received financial aid for the reconstruction of min. DK1 with the construction of a road junction. Efforts are underway to obtain partial financing of further road projects in the city.

The most important road investments planned in Czestochowa for the coming years are [6]:

- Modernization of DK-1 including construction of flyovers over the intersections with ul. Legionów and from ul. Krakowska;

- Reconstruction of DK-1 from the junction with ul. Jana Pawła II to the intersection with ul. Rakowska;

- Reconstruction of the outlet to Opole, ul. Główna and Przejazdowa - DK-46 together with the construction of an ambulatory for the church of St. Barbara to ul. Pulaski in Częstochowa. Currently under construction at the design stage in the "design and build" system;

- Connection of the Mickiewicza roundabout with ul. Krakowska along with the viaduct over the railway tracks;

- Extension of ul. Obrońców Westerplatte to the hospital in Parkitka;

- Connection of the newly built ul. Korfantego from ul. Bugajska leading to Olsztyn;

- A new exit to Olsztyn (al. Wojska Polskiego with ul. Bugajska) with an overpass over the railway tracks and a two-level junction on DK-1.

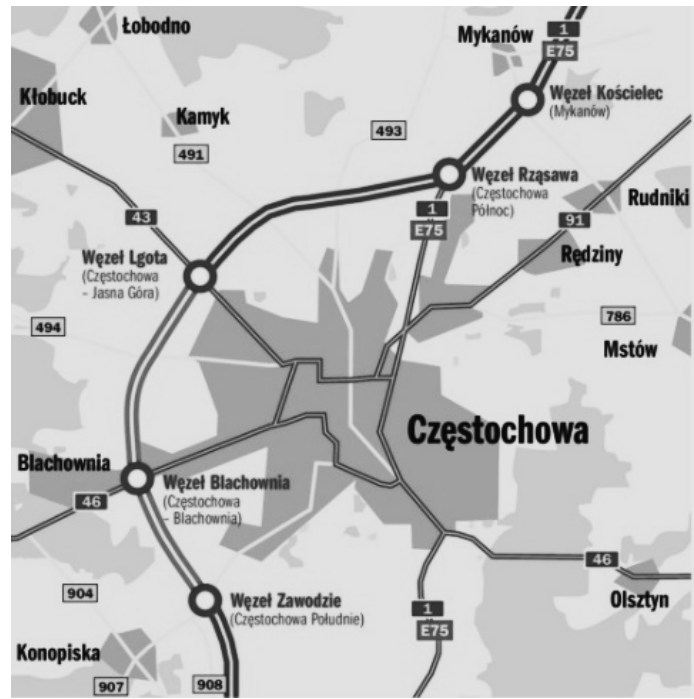

Fig. 1. The highway ring road of Częstochowa; arrangement of individual nodes [czestochowa.wyborcza.pl] 
These investments are of paramount importance for the modernization and expansion of the city's road system and its connection with the A1 [7]. The effect of the two largest of these investments - the reconstruction of DK1 and the completed construction of the motorway ring road (Fig. 1) is to increase the city's transport accessibility, better capacity of DK1 and A1, improvement of traffic safety and reduction of nuisances related to excessive road traffic in Częstochowa.

\section{The north corridor in the background of other completed road investments}

Part of the northern bypass of the city is the Northern Corridor. Its construction was carried out in stages. As for the route of this road, there were many variants, environmental analyzes and public consultations. After the analysis of this project, it turned out that the current route of the Corridor is the best in terms of the intended transportation effect, which was the connection of two large districts of the city with each other and with the DK1 road. It was also important to relieve the overloaded communication routes passing through the center of Częstochowa due to the lack of such a connection. $[2,8]$.

At present, stages I and II of part I of this investment have already been completed, i.e. a new street between the intersection of Michałowskiego and Fieldorfa-Nila streets and the intersection of św. Brata Albert and Narcisowa, and the renovation of ul. św. Brata Albert to ul. Makuszyński (Fig. 2). Ultimately, the Northern Corridor is to be extended westwards towards Kiedrzyn and eastwards to ul. Rząsawska and to DK91. Construction works should start in 2022.

In the future, this part of the road is to be an element of the transportation system supporting passenger car traffic in the northern part of the city. However, for economic reasons, the construction of further sections of the Corridor is not planned in the near future, covered by the Multiannual Investment Plan. It is also not intended to be a transit route, this role is taken over by the city's motorway ring road.

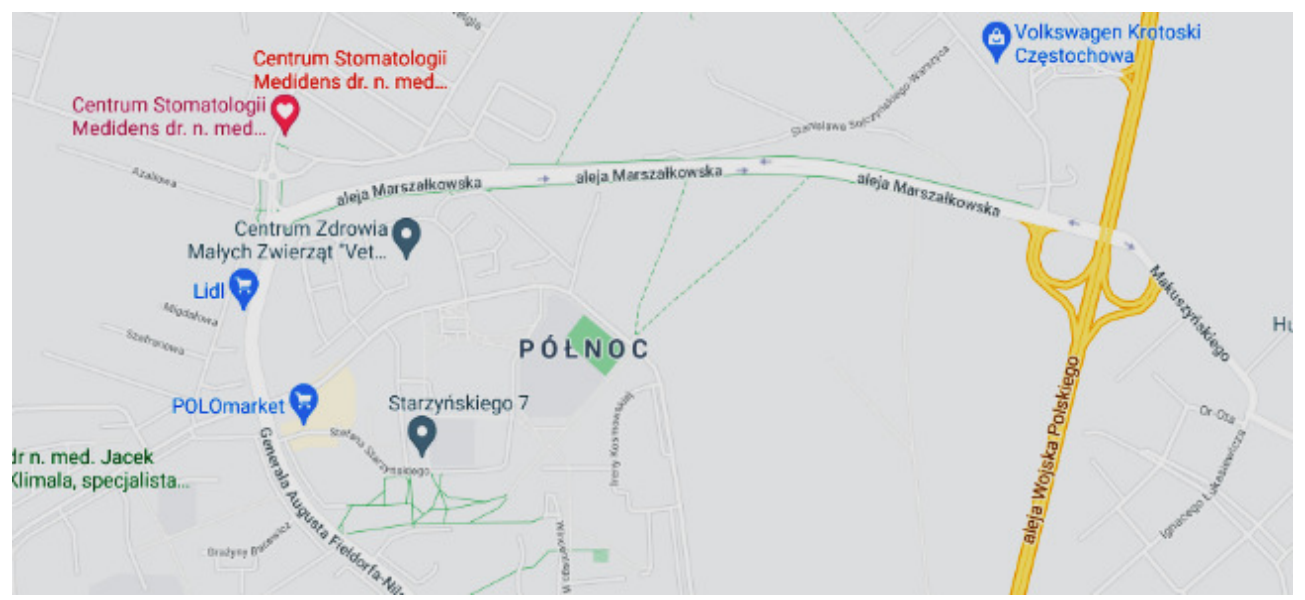

Fig. 2. The course of the Northern Corridor along with the junction connecting the road with DK 1 [google.com/maps/]

Construction of the already completed section of KP and the intersection of ul. Makuszyńskiego with DK1 in the form of a junction significantly reduces the travel time from the North district to the south of the city, the Raków and Błeszno districts, and vice versa. By using this road, you avoid having to cross the transit roads in the city center. Residents of opposite districts can save min. 20 minutes by car, which significantly reduces travel costs and indirectly contributes to environmental protection, reducing fuel consumption and the formation of exhaust gases. Driving from one neighborhood to another through the center takes approxi- 
mately twice as long [9]. Apart from the undoubted benefits for the inhabitants of the city, the journey of drivers from all over the region and Silesia, who do not have to stand in long traffic jams, wanting to get to, for example, Lubliniec or Opole, has been facilitated. Connection of ul. Makuszyńskiego from ul. Pilecki and a fragment of KP provide excellent transit routes with the investment areas of Częstochowa in Rząsawy. In the vicinity of the planned motorway junction in the Rząsawa district, there is a lot of undeveloped land, the potential of which will be possible to use in the coming years. A logistics center is to be built on this land. It will have better transport services and that region will benefit from it. At the moment, documentation is being prepared for the construction of the first section of the northern corridor going eastwards. Full design documentation is to be prepared in 2021.

The Northern Corridor is not the only road investment completed in Częstochowa in recent years. The other most important completed investments are [6]:

- Construction of the city bypass along with parts of the A1 motorway;

- Construction of a viaduct at the intersection with DK-46; connection with ul. Silver;

- Construction of an extension of Aleja Bohaterów Monte Cassino to ul. Śląska;

- Reconstruction of Aleja Pokoju on the section from DK-1 to ul. Rejtana with the construction of ul. Rejtana in Częstochowa;

- Reconstruction of DK-91 in Częstochowa - ul. Warszawska and ul. Rędzińska with the construction of the DK-91 junction with DK-1;

- Reconstruction of al. Wyzwolenia along with an underground passage.

The construction of the Northern Corridor is an element of the Better Communication program, under which one of the priorities is to connect the city road network with the junctions of the A1 motorway bypass. After the reconstruction of DK1, the connection with the northern motorway junction will improve, and in addition, it will allow for a collision-free passage through almost the entire city in the north-south relation.

\section{Summary}

The commissioning of the Częstochowa section of the A1 motorway was of key importance for the spatial development of Częstochowa, the creation of new jobs, the construction of shopping centers and logistic bases. Due to the problem of unemployment, it is becoming increasingly important to stimulate economic activity and create new jobs. It can be assumed that the construction of new enterprises in the Częstochowa Special Economic Zone will bring a good effect [10]. However, this can only take place if the connection of this zone with the future A1 motorway is improved. This route is also the northern and western beltway of Częstochowa, and access to it is provided by four collision-free junctions in the districts of Rząsawa, Grabówka, Gnaszyn and Dźbów. According to experts, the construction of the Częstochowa section of the A1 motorway will reduce the transit use of national roads running through Częstochowa - 1, 43, 46 and 91 [11].

The lack of a well-shaped, typically peripheral street layout was a drawback of the city's transport system [5]. As there were no ring roads serving external traffic, mainly on voivodeship and poviat roads, transit traffic was handled through city streets. Thus, the traffic was concentrated on the main street routes. After the construction of the city bypass, the situation changed dramatically.

Częstochowa currently has approximately 220,000 inhabitants. It should be noted that the majority of people are of productive age and that the largest workplaces are located outside the city center, which is naturally associated with a high traffic load during peak hours. Moreover, it should be emphasized here that for several years there has been a noticeable increase in individual transport, which often results in the city's transport paralysis, especially in periods involving road works.

Taking into account all these aspects, it should be noted that any road investments aimed at improving the quality of internal transit in Częstochowa and its proper configuration with the network of already existing roads will improve both the infrastructure itself and will 
contribute to reducing the travel time, as discussed in The article Northern Corridor to improve the economy of road traffic for the city of Częstochowa, which will also significantly affect the development of the city itself.

\section{References}

[1] Serwis Gov.pl Ministerstwo Infrastruktury Transeuropejska sieć transportowa - TEN-T.

[2] Urząd Miasta Częstochowy ( fe.czestochowa.pl) Narodowa strategia spójności.

[3] Ministerstwo Infrastruktury i Rozwoju, zał. Nr 1, projekt do Programu Budowy Dróg Krajowych na lata 20142023 z dnia 22 XII 2014.

[4] Serwis Programu Infrastruktura i Środowisko (na lata 2014-2020), 4.1 Zwiększenie dostępności transportowej ośrodków miejskich leżących w sieci drogowej TEN-T i odciążenie miast od nadmiernego ruchu drogowego, 7 listopada 2016

[5] Sołkiewicz-Kos N., Transformation directions of downtown areas on the example of the city of Częstochowa, Zeszyty Naukowe Politechniki Częstochowskiej 2016, seria Budownictwo 22, 291-297.

[6] slideplayer.pl „Ewaluacja projektu współfinansowanego ze środków Unii Europejskiej”.

[7] Nowoczesne budownictwo inżynieryjne www.nbi.com.pl.

[8] Dokumentacja Powykonawcza dla inwestycji „Budowa Północnego Korytarza w Częstochowie, Etap II od ul. św. Brata Alberta do ul. K. Makuszyńskiego” z dnia 12.07.2013.

[9] czestochowa.naszemiasto.pl „Korytarz północny”.

[10] Urząd Miasta Częstochowy (bip.czestochowa.pl) Specjalne strefy ekonomiczne.

[11] Urząd miasta Częstochowa MZDiT „Plan zrównoważonego rozwoju publicznego transportu zbiorowego dla Miasta Częstochowy".

\section{Korytarz Północny - ekonomiczne rozwiązanie komunikacyjne w infrastrukturze miasta Częstochowa}

\section{STRESZCZENIE:}

Przedstawiono zrealizowane oraz planowane inwestycje drogowe wpływające na ekonomiczne rozwiązania komunikacyjne miasta Częstochowa. Dokonano oceny wpływu inwestycji drogowej, tzw. Korytarza Północnego, na ekonomię komunikacyjną obejmującą realizację zamierzonego efektu komunikacyjnego. Wskazano również inne zrealizowane i planowane inwestycje komunikacyjne dla miasta Częstochowa. W podsumowaniu wskazano na celowość poprawy ekonomiczności ruchu kołowego miasta Częstochowa, co w wydatny sposób wpłynie również na rozwój samego miasta.

SŁOWA KLUCZOWE:

infrastruktura drogowa; autostrady; drogi ekspresowe; drogi krajowe; sieć drogowa Częstochowy 